\title{
Vozes na sanzala (kahitu), de Uanhenga Xitu, e Quantas madrugadas tem a noite, de Ondjaki: expressões literárias de uma sociedade em mudança
}

\author{
Edelson Santana de Almeida* \\ Marilúcia Mendes Ramos**
}

\begin{abstract}
Resumo
objetiva-se analisar dois momentos distintos da produção literária de Angola: o primeiro, da literatura de resistência de Uanhenga Xitu, com base na leitura da narrativa Vozes na sanzala (Kahitu) (1984), por meio da qual serão apresentadas considerações sobre a constituição da personagem Kahitu e suas implicações com a representação do ambiente angolano ainda em período colonial; o segundo, volta-se à escrita que retrata o quotidiano contemporâneo de Luanda em Quantas madrugadas tem a noite (2004), de Ondjaki, que permitirá a sondagem de elementos constituintes da narrativa, além de observações acerca do contexto de produção. Serão destacados, assim, os processos de mudanças pelos quais passou a sociedade angolana, retratados tanto em um contexto de colonialismo, quanto no período pós-colonialista, que aparece representado na narrativa contemporânea escolhida.
\end{abstract}

\section{Palavras-chave}

Literatura africana. Narrativa angolana. Colonialismo. Uanhenga Xitu. Ondjaki.

A instalação da tipografia em Angola, no fim da primeira metade do século XIX, propiciou a expansão da imprensa local e também o aparecimento do primeiro livro impresso na África lusófona, Espontaneidades da minha alma (1849), do poeta angolano José da Silva Maia Ferreira, de acordo com Ferreira (1977). Com a consolidação dos jornais impressos e de revistas como A Aurora (1856), em Luanda,

\footnotetext{
* Mestrando em Estudos Literários do Programa de Pós-Graduação em Letras e Linguística da Universidade Federal de Goiás. E-mail: edelsonsantana@hotmail.com.

** Professora Associada da Universidade Federal de Goiás. Doutora em Letras (Estudos Comparados de Literatura de Língua Portuguesa) pela Universidade de São Paulo. E-mail: marilucia_ramos@uol.com.br.
} 
tornam-se públicas as primeiras manifestações literárias a expressarem sentimentos em tons nacionais, representadas pela produção dispersa de alguns poucos escritores da terra. No campo da narrativa, destaque para o romance Nga Mutúri, publicado em folhetins pelo jornalista Alfredo Troni, que retrata aspectos da sociedade luandense. Santilli (1985) assinala, entretanto, que apesar do início do surgimento de condições para a criação das modernas literaturas nacionais na África lusófona, no século XIX, a obra que mais marcadamente demonstra a procura de uma identidade na literatura angolana surge somente no século seguinte, tratando-se de $O$ segredo da morta, romance de costumes angolanos publicado em 1929 no jornal $A$ Vanguarda, também em folhetins, por Antônio de Assis Júnior.

Após um período de escassa produção literária, intelectuais angolanos começam a buscar meios de divulgação de suas obras. Assim, o "Movimento dos Jovens Intelectuais de Angola" organiza a Antologia (1950), reunindo uma nova geração de poetas. Posteriormente, as revistas Mensagem (1951-1952) e Cultura II (1957-1961) contribuiriam com a formação de importantes escritores, como Agostinho Neto e Luandino Vieira. Uma década depois, despontariam nomes como Jofre Rocha e Agostinho Mendes de Carvalho (Uanhenga Xitu), cujas obras seriam fundamentais para a construção de uma literatura voltada à reflexão de Angola frente à opressão dos colonizadores. Escritores dessa geração engajam-se na luta contra o colonialismo português, utilizando a literatura como instrumento de conscientização de parte da população para a causa angolana. Em 1961, iniciam-se as ações do Movimento Popular de Libertação de Angola (MPLA), comandado por Agostinho Neto, sendo sua organização uma das principais forças contra a dominação portuguesa, regida pelos ideais fascistas do regime salazarista.

A Revolução dos Cravos, em 25 de abril de 1974, põe fim ao salazarismo, colaborando com a conquista da emancipação política das colônias portuguesas, que, em Angola, ocorreria oficialmente mais de um ano depois, em 11 de novembro de 1975, data de sua independência. Sabe-se que a simples retirada das forças portuguesas do território angolano não representou, necessariamente, a instauração de tempos de plena liberdade à população local. Em época de Guerra Fria, conflitos ideológicos entre o MPLA - movimento de caráter socialista financiado pela então União Soviética - e os grupos Frente Nacional de Libertação de Angola (FNLA) e União para a Libertação Total de Angolana (UNITA) comprometeriam seriamente a possibilidade de um Estado sólido política e economicamente.

Atualmente, o projeto de construção de uma nova sociedade em Angola continua em andamento. Aliadas à instabilidade política interna, ainda estão as sequelas do período de dominação colonial, quando o poderio europeu procurou "colonizar mental e espiritualmente o homem africano" (SERRANO; WALDMAN, 2007, p. 222), sem, no entanto, transferir para aquela terra qualquer conhecimento tecnológico ou científico.

Mesmo em um contexto adverso, a literatura angolana continua pulsante. A despeito da renovada configuração social e política do país, sua temática mantém o tom de denúncia das mazelas sociais, típicas de países que ainda lutam por melhores condições de vida ao seu povo e pela independência econômica em um mundo 
movimentado pelo capitalismo financeiro. Após a independência oficial de Angola, prosadores "mais-velhos" como Luandino Vieira e Uanhenga Xitu, ao lado de muitos outros combatentes pela libertação de Angola, publicam seus escritos, muitos deles produzidos nas prisões a que foram submetidos por vários anos e abrem espaço para uma geração de novos escritores, entre outros nomes, Pepetela, José Eduardo Agualusa e Ondjaki, que buscam conciliar a carga de tradição africana por eles herdada com temáticas inerentes à contemporaneidade.

O presente trabalho terá por objetivo analisar dois momentos distintos da produção literária de Angola. O primeiro deles diz respeito à literatura de resistência empreendida por Uanhenga Xitu. A partir da leitura de Vozes na sanzala (Kahitu) (1984), serão apresentadas considerações a respeito da constituição da personagem Kahitu e suas implicações com a representação do ambiente angolano ainda em período colonial. $O$ outro momento volta-se à escrita que retrata o quotidiano contemporâneo de Luanda, levada a cabo pelo jovem Ondjaki. Uma breve leitura de Quantas madrugadas tem a noite ${ }^{1}$ (2004) permitirá a visualização de elementos constituintes da narrativa, além de observações acerca do contexto de produção, já que, quando se trata de literatura produzida em África, concordando com Venâncio (1992), "é um erro crasso analisar um texto literário independentemente do respectivo contexto cultural e político" (p. 26). Ainda seguindo essa ideia, serão destacados os processos de mudanças pelos quais passou a sociedade angolana, retratados tanto em um contexto de colonialismo, como demonstra o texto de Uanhenga Xitu, quanto no período pós-colonialista, que aparece representado na narrativa contemporânea de Ondjaki.

\title{
Vozes na Sanzala: expressão de um mundo em transição
}

\begin{abstract}
Porque morrer é uma ou outra destas duas coisas: ou o morto não tem absolutamente nenhuma existência, nenhuma consciência do que quer que seja, ou, como se costuma dizer, a morte é precisamente uma mudança de existência e, para a alma, uma migração deste lugar para um outro.

Sócrates
\end{abstract}

No final da década de 1950, a sociedade de Angola vivia um de seus mais conturbados momentos políticos. Intelectuais conhecedores do socialismo a Fidel Castro fundam o MPLA, e o seu líder, Agostinho Neto, seria logo preso pela Polícia Nacional de Defesa do Estado (PIDE), que se instalara no local. Seguiam-se prisões maciças de cidadãos angolanos defensores da causa nacionalista e repressões a manifestações populares pacíficas ou não, ocasionando eventos sanguinários, como o massacre de Icolo e Bengo (DILOLWA, 1981).

Foi nesse contexto que Uanhenga Xitu escreveu Vozes na sanzala (Kahitu). Estava na prisão de Tarrafal, Ilha de Santiago, em Cabo Verde, onde cumpriu pena por mais de dez anos, acusado de "exercício de atividades contra a segurança do Estado" (XITU, 1984, p. 28). O escritor permaneceu sob custódia da Polícia Política de Salazar

\footnotetext{
${ }^{1}$ Utiliza-se para este estudo a primeira edição brasileira da obra, publicada em 2010 pela editora Leya.
} 
entre os anos 1959 e 1970, o período de mais intensa repressão aos angolanos resistentes à força colonizadora.

Em Vozes na sanzala, Xitu descreve literariamente o espaço rural angolano, localização mais favorável à manutenção de práticas tradicionais africanas. Embora Luanda, à época, começasse a formar um setor industrial, composto basicamente de indústrias extrativistas e transformadoras, por força do capital estrangeiro, a maior parte da população angolana vivia na zona rural, onde exerciam atividades relacionadas basicamente à agricultura. Kahitu, o protagonista da obra, é um personagem que não conhece outro lugar que não seja a sua sanzala, sem, no entanto, em sua permanência, deixar de notar as mudanças pelas quais, inevitavelmente, passa o seu meio.

O narrador de Vozes na sanzala desde o início demonstra total conhecimento acerca do objeto narrado, como se observa nas primeiras linhas do capítulo de abertura - "Kahitu", destinado a apresentar o protagonista: "Era paralítico de infância. Desde a nascença nunca ficou de pé" (p. 35). Trata-se do primeiro contato com o condutor da narrativa, que, detentor da história, preocupa-se em transmiti-la de modo compreensível e até didático.

No entanto, percebe-se uma outra preocupação: dotar de verossimilhança a história narrada. Ainda no capítulo inicial, aquele que introduz o protagonista, esboçase como possível causa da deficiência física de Kahitu a quebra de preceitos tradicionais efetuada por seu pai, Makita. Em sua onisciência, o narrador expõe uma conversa íntima entre Mbombo, a mãe do protagonista, e Makita, na qual a mulher expressa sua angústia mediante a possibilidade de reincidência da doença do "kikata", pois o esposo deixara de cumprir recomendações deixadas por curandeiros a seus antepassados.

Todos os incidentes que levaram à promessa e à sua quebra são relatados pormenorizadamente, em analepse, no capítulo seguinte, denominado "Kituta". Apesar de considerável distância temporal, já que os eventos propiciadores do defeito físico de Kahitu tiveram origem em um ato ocorrido com a sua avó, a narração é repleta de detalhes e explicações. Tem-se, nos parágrafos iniciais desse capítulo:

Velha Kaualende, numa madrugada, levou a sua disanga às costas e dirigiu-se à fonte de Kasadi. Não era vulgar as pessoas "amadrugarem" para tirar água daquela nascente.

Kaualende fê-lo, porque tinha muito que fazer e, nesse dia, o trabalho para ela começava de madrugada.

A mulher, pelo caminho, ia pensando no programa do dia. O carreiro por onde passava mal se via. O capim alto, pesado de dimune, vergava sobre o caminho, impedindo a passagem. De vez em quando, com as mãos, a rapariga afastava o mbulu e o disenu que dificultavam o andamento. Outras vezes, com a ajuda de um pau, ia batendo no musoke para deixar cair o orvalho que lhes molhava os panos (XITU, 1984, p. 39).

No que concerne à construção narrativa, observam-se, a partir do fragmento acima destacado, precisa marcação temporal ("numa madrugada") e minuciosa descrição do espaço, com olhares voltados à vegetação rasteira local, cenário em que 
desenrolam as ações. Vê-se um narrador incontestavelmente onisciente, capaz de reproduzir o pensamento da personagem e explicar os seus procedimentos. No trecho, encontram-se ainda observações relativas aos costumes sociais ("Não era vulgar as pessoas 'amadrugarem' para tirar água daquela nascente" - XITU, 1984, p. 39), as quais poderão ser detectadas ao longo de toda a narrativa.

Ao fim do capítulo que explica as raízes do problema físico de Kahitu, assim expressa o narrador: "Aí fica a verdade de como o Mbombo viera para este mundo" (XITU, 1984, p. 52. Grifos nossos). O uso da palavra "verdade", precedido de artigo definido, é mais uma comprovação de que aquele que conta quer se fazer confiável. Daí tantas descrições, explicações e a afirmação de veracidade dos fatos narrados.

Os capítulos seguintes mostram, linearmente, a trajetória do protagonista. "Kaxena" retrata a convivência de Kahitu com outras crianças, momento em que começa a despontar nele a característica de mestre, por ensiná-las artes diversas, como os jogos, a confecção de instrumentos para caça e retirada de frutos do imbondeiro e natação. Nesse capítulo, o personagem começa a merecer o respeito de todos de seu meio, que passam a admirar a sua engenhosidade e deixam de ridicularizá-lo por sua deficiência física.

"Escola" ilustra o período de aprendizagem, quando Kahitu ingressa no ensino formal, mas fica por pouco tempo, já que estudos mais avançados eram oferecidos somente em lugares muito longe da sanzala, impossibilitando o deslocamento do interessado "kikata". Aqui, o protagonista inicia-se na valorizada profissão de ferreiro, cuja técnica ele havia aprendido com os mais velhos, ao mesmo tempo em que cuidava de um grupo de crianças, os seus primeiros pupilos.

Em "Cartório", percebe-se a consolidação da figura de mestre. Kahitu passa a ser retratado como exímio ledor e escrevedor de cartas aos mais velhos, demonstrando perfeito domínio de um português ainda pouco acessível à maioria. Nesse capítulo, o personagem é descrito como "mestre ferreiro, conselheiro, escrevente e dirigente dos miekeieke" (XITU, 1984, p. 67), visto o consistente conhecimento que já detinha acerca da história e dos costumes de sua comunidade.

Nesses três capítulos acima mencionados - "Kaxena", "Escola" e "Cartório" - o narrador dedica-se à caracterização do protagonista, realçando-o à categoria de mestre. Nota-se que a conferência desse status é construída gradualmente: enquanto em "Kaxena" a primeira ocorrência da palavra "mestre" atribuída ao personagem vem entre aspas ("Kahitu foi durante muito tempo, ou toda a sua vida, o 'mestre' das crianças" - XITU, 1984, p. 54), em "Escola", após o período de educação formal e o domínio da técnica de ferreiro, Kahitu vem caracterizado como legítimo mestre de sua sanzala. Para observar a sua descrição, vale o esforço da leitura da longa citação, construída por superlativos:

O mestre era o homem mais informado da sanzala. Estava a par de todas as conversas, até das íntimas. Conhecia a fundo o segredo de algumas famílias. Porque, enquanto os seus contemporâneos faziam da sanzala lugar de transição ele estava lá desde a nascença. Viu velhos e novos a morrerem, e crianças a nascerem. Assistiu a casamentos e divórcios. Conhecia todo o verbo e adágios regionais para conquistar mulheres. Também sabia derrubar um argumentador 
astucioso. E servia como orientador de muitos rapazes para conquistarem moças, e conselheiros de moças para se escaparem de rapazes com más intenções (XITU, 1984, p. 61).

Essa forte característica do protagonista é reafirmada no capítulo "Kizolexa", onde o termo "mestre", referindo-se ao personagem, supera o uso do nome próprio. O substantivo "mestre", dessa forma, passa a ser utilizado como substituto ao antropônimo "Kahitu", consolidando a sua condição de sábio detentor de vasto conhecimento e diferenciando-o das demais personagens. É nesse capítulo, no entanto, que se introduz Saki, a personagem responsável por desencadear a queda do mestre. Nessa parte, em que é descrita Saki, torna-se ainda mais visível a participação do narrador, que suspende a narração para contar um caso ocorrido com Sange, que muito revela a respeito dos costumes locais. O narrador, nessa passagem, assim se pronuncia:

Talvez fosse mais conveniente interromper a narração sobre a menina Saki de saki e malumbi para resumir o muito falado caso de Sange. Mas peço aos leitores para não perderem a meada (XITU, 1984, p. 79).

Dessa maneira, o narrador mais uma vez realça a sua tarefa de condutor da história. Um condutor, como já se afirmou, que busca dar veracidade à enunciação e, como apontou o trecho, preocupa-se com a questão da compreensibilidade, mostrando-se consciente do papel do leitor, que, por sua vez, assume a posição de interlocutor. Tal procedimento levado para o texto escrito faz parte das preocupações dos narradores das histórias transmitidas oralmente, conforme as tradições africanas.

Com a introdução da personagem Saki na narrativa, a caracterização de mestre atribuída gradativamente a Kahitu começa a sofrer significativo abalo. No capítulo sugestivamente denominado "Sai njimu, sai hete", essa imagem passa a ser desconfigurada assim que o protagonista dá início ao seu assédio à jovem, até então sua discípula. Com essa ação, começa-se a por em xeque o status de mestre atribuído a Kahitu, como poder ser visualizado nos fragmentos abaixo:

\footnotetext{
Novamente, a Saki, para casa, ia pensando no mexerico que existia na monomania do "mestre" (XITU, 1984, p. 84).

O "mestre" que se encontrava doente, uma diarréia, mandou portador à Saki para que lhe enviasse um pouco de matete (XITU, 1984, p. 84).

O "mestre", sentado à cabeceira da cama, xenou até ao outro extremo, onde estava encostada a moça e pegou no pano com que Saki cobria o tronco (XITU, 1984, p. 85).
}

A imagem quase sacralizada de Kahitu desconstroi-se fortemente após os seus encontros amorosos com Saki, que, em momento de reflexão sobre os seus contatos íntimos com o protagonista, conclui: 
Muita gente fala mal do aleijado. Atribui-Ihe calúnias de andar a desviar os jovens. [...] cometi uma grande falta, deixar-se despir por um homem! Mas ele não é home, ele é um kikata (XITU, 1984, p. 86. Grifos nossos).

E é como um aleijado, e não como o sábio, que Kahitu será levado ao tribunal, ao final da narrativa, após a revelação de que seria dele o filho esperado por Saki. Agora, a posição de mestre é totalmente apagada, sobressaindo-se a figura do paralítico:

Com a confissão do escândalo invulgar - um paralítico como Kahitu, engravidar a simpática e querida Saki - houve uma manhã agitada (XITU, 1984, p. 102. Grifos nossos).

Neste Tribunal tão bem ornamentado pela Natureza, julga-se o primeiro caso dessa espécie; em que um paralítico de nascença - e que paralítico! - engravida uma das raparigas mais requestadas nos últimos tempos (XITU, 1984, p. 103-104. Grifos nossos)

Quanto às mudanças sociais, um primeiro aspecto a ser observado refere-se à instalação de escolas e ao estabelecimento de uma educação formal em solo angolano nos moldes europeus. À alfabetização foi atrelada poderosa inculcação de valores ideológicos dos colonizadores, como se vê no início do capítulo "Escola":

Quando o esperado professor chegou à sanzala, Kahitu já sabia ler todo o livro de "João de Deus" e o de "Deveres dos Filhos". Ele sabia mais que alguns dos antigos seus explicadores.

Na aula, o professor prestava-Ihe muita atenção. Fez-Ihe a revisão dos livros que já acabara e passou-o para a Leitura Pequena, de João Grave, era assim como se chamava o livro da primeira classe. (XITU, 1984, p. 57)

Na Angola colonialista, o ensino era dividido em duas categorias: o missionário, direcionado aos "indígenas", de caráter rudimentar e doutrinador; e o oficial, dirigido para uma minoria composta de europeus e assimilados, com programas de ensino semelhantes aos vigentes na Metrópole (BOAVIDA, 1981). O professor de Kahitu, representado no fragmento acima, certamente é um assimilado que, após ter aprendido o básico da língua portuguesa, dedica-se à retransmissão desse conhecimento aos mais jovens. Depois, a falta de condições para a manutenção desse mestre faz com que os aprendizes deixem a sanzala a fim de que pudessem dar continuidade aos estudos formais. Devido à sua deficiência física, Kahitu passa a maior parte da vida na sanzala e entrega-se ao aprendizado de técnicas tradicionais, tornando-se exímio ferreiro.

A imposição de um ensino centrado na língua e, consequentemente, na cultura do colonizador, faz configurar novas práticas em detrimento a crenças tipicamente africanas consolidadas ao longo de séculos. No início da narrativa, após o relato da quebra de preceitos realizada por Mukita na ocasião da gestação de Kahitu, personagens mais velhos expressam sua preocupação quanto à mudança de costumes, vista por eles de modo negativo: 
- Ah, mesene Kilamba - interrompeu um dos velhos presentes - hoje, é escusado, os nossos filhos não ligam a essas coisas. Vieram os homens da Missão...

- E que desrespeito, cantam e assoviam atrevidamente os hinos da Missão, mesmo quando estão a tomar banho nas águas do Ngna Kasadi! - disse um outro velho, num tom muito aborrecido. (XITU, 1984, p. 45)

A situação de assimilação da cultura europeia chega ao ponto de Kahitu, dotado de conhecimentos bíblicos, ser descrito como um "bom cristão" que "cantava como um anjo" e, nos espetáculos da Igreja, fazia o papel do "coxo dos Apóstolos João e Pedro" (XITU, 1984, p. 61). Posteriormente, a "escola de civismo" ensinaria aos jovens aquilo que aprendeu o "kikata de Deus" (p. 75). Nota-se o uso que o poder colonial acabou fazendo de Kahitu, ao notar sua vontade de aprender e sua inserção junto aos jovens.

Vozes na sanzala ilustra ainda mudanças comportamentais, especialmente entre os mais novos. A personagem Kanvula, por exemplo, não aceita a ideia de casamento por imposição, fazendo valer o direito de casar-se com o homem por ela amado, Mbenza, que, por sua vez, é rejeitado pelos pais da moça devido a makas ocorridas em um passado relativamente distante. Kanvula tenta mostrar que os novos tempos pedem a renovação de valores: "- Costumam dizer que é por causa dumas conversas que passou muito tempo com meu avô e avô do Mbenza. Eles já morreu. Eu tenho coisa com isso?" (XITU, 1984, p. 69).

Outras personagens femininas também são exemplos dessa sociedade cujos valores encontram-se em transição: Sange, que resiste às investidas do marido e, propositalmente, deixa de cumprir o "dever sagrado da mulher" por ter sido raptada contra a sua vontade; e Saki, uma mulher muito esclarecida a respeito da natureza dos homens, mas que se entregaria à vontade de Kahitu, engravidando-se dele. Tais modificações vão exemplificando as profundas transformações que o sistema colonial foi promovendo lentamente nas comunidades tradicionais.

O envolvimento com Saki, e sua consequente gravidez, levou Kahitu ao Tribunal. Apesar das mudanças comportamentais que já se via na sanzala, o mestre, único de seus habitantes que, por seu histórico, não podia se desvirtuar, já estava socialmente condenado. A angústia do réu é narrada em discurso indireto livre, ocorrida na véspera do julgamento público, no parágrafo mais extenso da narrativa:

\footnotetext{
Consideram crime grave a um caso tão vulgar só porque sou paralítico! Assisti tantos casos desta natureza durante a minha vida e nunca houve tanto barulho, alarme! [...] Se de fato sou um dos enviados do Kituta de Kasadi, como dizia a minha mãe, porra, alguma vez na vida esta Kituta me ajudará. Lembro-me quando novo e frequentava a Igreja e na cena de textos bíblicos que se referiam ao paralítico eu gritava: "Jesus, filho de David, tenha misericórdia de mim!" Houve momentos que sentia a impressão de que os pés estavam a querer mexer-se. Mas fiquei desiludido, não obstante a fé, a fé que o mano Pedro, fanático, recomendava. Textos de um passado e de um povo que a história registou. Se tu és Kituta mesmo, Kituta de Kasadi, da água que bebo e tomo banho, ao menos que tenha pena de mim... (XITU, 1984, p. 104).
}

Esse discurso em autodefesa dialoga com dois consagrados textos da cultura ocidental: uma defesa de Sócrates, registrada por Platão, denominado Apologia de 
Sócrates, e o Novo Testamento. No primeiro, o filósofo grego profere um brilhante discurso, no qual se defende da acusação de corromper os jovens atenienses. 0 segundo refere-se a uma passagem em que Jesus Cristo, repetindo palavras dos Salmos de David, expressa o seu sofrimento diante da aproximação do momento de sua crucificação: "Pai, por que me abandonaste?".

Em seu desabafo, Kahitu denuncia a vulgaridade do caso - a gravidez de uma jovem solteira, algo já nem tanto abominável para aquela sociedade em ampla transformação. Considera que o exagerado escândalo provocado por seu feito deveuse mais ao seu defeito físico do que ao fato de se ter sido considerado "crime hediondo". Dessa forma, deixa claro que o ambiente em que estava inserido, por ele muito bem analisado em sua inevitável fixidez, passava por um processo de reconfiguração. Ao final, percebendo que o apego aos símbolos cristãos, estrangeiros, de nada valeriam para livrá-lo de sua terrível situação, volta-se às raízes maternas, recorrendo aos mitos de sua terra ("Kituta de Kasadi"), em um processo de revisão de seus próprios valores, como se somente nessa trágica hora obtivesse a oportunidade de questionar uma cultura exógena que ele aceitou até a proximidade de seu fim.

\title{
Quantas madrugadas tem a noite: leitura da contemporaneidade
}

\author{
Ah, medo tenho não é de ver morte, \\ mas de ver nascimento. Medo mistério. \\ Guimarães Rosa
}

À primeira leitura de Quantas madrugadas tem a noite tem-se a impressão de se estar diante de um narrador heterodiegético e onisciente a apresentar casos por ele ouvidos na região de Luanda. No capítulo de abertura, "As primeiras ngalas", são apresentadas personagens dotadas de aspectos caricaturais. Faz-se entrar em cena a KotaDasAbelhas, o BurkinaFaçam, o Jaí e o protagonista, AdolfoDido.

KotaDasAbelhas é uma senhora que teve a sua residência invadida por abelhas. Ambiciosa, ela deixou que a colônia se estabelecesse para, em seguida, matar a abelha-rainha e tomar o comando das abelhas operárias, que produzem para si todo o mel. Além disso, a "kota" possuía um monstruoso cachorro, o Cão, animal feroz, que ocupava o maior espaço da casa, onde recebia tratamento de rei.

BurkinaFaçam e Jaí são os amigos de AdolfoDido, cuja morte passa a dominar a narrativa a partir do capítulo denominado "Morte morrida, de pessoa". Em um dia muito chuvoso, AdolfoDido é encontrado morto em seu lar e, ao ser encaminhado para o necrotério, instala-se uma grande "maka": KiBebucha e DonaDivina disputam a condição de viúva do homem falecido.

A disputa entre as duas senhoras recebe ares de telenovela brasileira devido aos seus imprevisíveis desencadeamentos. DonaDivina, contando com auxílio de militares influentes, retira o corpo do marido da morgue, levando-o para o Hospital Militar, onde seria autopsiado. Em reação, Kibebucha, acompanhada de uma advogada, por força policial, consegue a apreensão do corpo, que é levado a uma delegacia para 
averiguações. O ponto alto desse episódio é a revelação de que o motivo da briga entre as duas candidatas a viúva tem a ver com uma pensão que o governo passaria a conceder a esposas de antigos combatentes, conforme pode-se constatar pelo trecho:

Então: tava lá no jornal, na sequência da notícia dos assuntos parlamentares dos dorminhocos da Assembleia, que tava outro assunto no bailar das discussões atuais: as pensões, os cumbus todos dos antigos combatentes, que era maka antiga, com direito a ministério e tudo, mas não só isso e principalmente as damas dos ex-combatentes, quem ganhasse estatuto de viuvez. [...] Elas eram espertas então: viúva que comprovasse mesmo pura, nos laços com o ex-combatente, ia receber a pensão do gajo, mais um dinheiro extra pela morte do falecido, mais uma viatura - brincas, ou quê?, num te dizia o dinheiro move o mundo nas vintiquatro horas dele se renovar? (ONDJAKI, 2010, p. 70).

O caso de AdolfoDido tornou-se de interesse nacional, pois a mulher que comprovasse ter sido esposa do protagonista seria a primeira "viúva do estado", ou seja, a primeira a fazer uso do privilégio mencionado no fragmento acima, tendo direito à pensão e a outras regalias governamentais. Assim, a disputa chega à esfera jurídica, cabendo à JuízaMeritíssima decidir quem seria a legítima esposa do morto. $\mathrm{Na}$ imprensa, começam a repercutir histórias fantasiosas sobre o passado do "excombatente", que chegara, inclusive, a combater no Namibe, região desértica ao sul de Angola. No irônico capítulo "Missa de corpo ausente", relata-se uma espécie de "comício religioso", em que uma missa realizada em memória do falecido reúne as principais autoridades do local e transforma-se em importante evento social.

Ao final da narrativa, porém, para desilusão das viúvas, AdolfoDido levanta-se do caixão, "retorna à vida" e põe fim a toda confusão gerada por sua suposta morte. E a descoberta mais surpreendente virá no capítulo final, "A outra margem", quando o narrador revela ser ele próprio o protagonista da história que acaba de contar, manifestando-se da forma seguinte:

\begin{abstract}
Ouve inda, quero te agradecer puramente, ouviste bem a minha estória. Afinal não é só aquele que conta que conta: quem escuta calado também faz a estória. Se vais contar tudo isto nos teus cambas ou nos teus candengues, porra, num aumenta só mais essa estória - toda ela já é um espanto da vida, viagens todas incluídas, volta e vinda também. Mais até: no mô coração só vou guardar, pra sempre, o tô sorriso agora na minha derradeira sentença que eu largo aqui pra nos despedirmos já: o morto, esse morto que lhe bebemos aqui..., tou ta pôr: esse morto sou eu!, AdolfoDido, eu mesmo! (ONDJAKI, 2010, p. 177-78. Grifos nossos)
\end{abstract}

A revelação contida na passagem anterior faz perceber que se está diante de uma personagem narrando a eventualidade de sua própria morte. A construção narrativa de Quantas madrugadas tem a noite é semelhante à de Grande sertão: veredas, romance de Guimarães Rosa no qual o personagem Riobaldo, sem poupar digressões, narra a história de sua vida a um interlocutor que em momento algum se manifesta. A narrativa de Ondjaki remete ainda a um outro texto de Rosa, "Meu tio Iauaretê", que traz um narrador-protagonista a relatar o próprio ato de morrer. Um outro exemplar de narrador desse tipo a ser evocado é o Brás Cubas, o personagem defunto criado por Machado de Assis, que, após a vida, elabora suas memórias. 
No entanto, diferentemente dos personagens-narradores das obras de Guimarães Rosa e de Machado de Assis, o protagonista criado por Ondjaki narra em vida a sua própria morte, que passa a ser, para ele, um episódio supostamente "vivenciado". Assim, AdolfoDido relata a sua experiência de morte:

[...] Vim dali, onde chamam lá em cima, e vi tudo como num era pra ver, porque não era pra ter ficado lá, mas não sou dono do mundo da terra muito menos dono do mundo do céu: se mesmo Deus e o diabo falaram e me mandaram mais voltar aqui, querias que eu dissesse quê? Arrumei minhas nenhumas imbambas e vim só, no caminho da descida, o que me afligia mais era a sede, te confesso, te confessei já. (ONDJAKI, 2010, p. 178)

Adotando a terminologia proposta por Genette (1979, p. 243), que considera inadequado o termo "narrativa na primeira - ou na terceira pessoa", uma vez que

a escolha do romancista não é feita entre duas formas gramaticais, mas entre duas atitudes narrativas (de que as formas gramaticais são apenas uma consequência mecânica): fazer contar a história por uma das suas "personagens", ou fazer contar a história por um narrador estranho a essa história,

podemos afirmar que o narrador de Quantas madrugadas tem a noite, em relação ao nível narrativo, é um narrador intradiegético e, em relação à história narrada, é um narrador autodiegético. Assim, nessa obra, encontra-se um narrador de primeiro nível a organizar sua própria história. AdolfoDido é, ao mesmo tempo, protagonista e narrador da história por ele organizada, pertencendo, portanto, ao universo diegético dessa narrativa.

Todos os eventos constituintes do relato empreendido por AdolfoDido são muito bem engendrados. O tempo da narração compreende exatamente o período entre "as primeiras ngalas" (por acaso, nome do capítulo de abertura) à última cerveja, a popularmente chamada "saideira". A história é contada para distrair um interlocutor anônimo que, em contrapartida, assume a conta da bebida consumida:

Avilo, prepara só mais umas cervejas, porque tamos quase a chegar no fim, mas não vamos funcionar com as pressas - aqui tem que ser tudo no tempo de cada birra, nós aqui sentados como sempre estivemos, nada de avança-avança de atropelar as recordações e os momentos da pura nossa história. Sem kijila - a estória tem que ser bem zungada e eu tou aqui pra isso. (ONDJAKI, 2010, p. 150)

O fato de o narrador consumir bebida alcoólica, ação que poderia afetar o seu estado de lucidez, parece ser insuficiente para caracterizá-lo como um "narrador não confiável", ou unrealible narrator, em oposição ao termo realible narrator, na distinção proposta por Booth (1983). Pelo contrário, AdolfoDido demonstra ter plena consciência daquilo que narra e do modo como deve ser narrado, já que sua intenção primeira é prender a atenção do interlocutor e, por consequência, de um virtual leitor. Não raro, aparecem comentários a indicarem a existência de um autor implícito, com um projeto textual preestabelecido, como no texto abaixo, metanarrativo: 
O quê, avilo? Não, eu num menti nada, aqui não há mentiras nem confusões, eu te falei mesmo a verdade: na igreja num tinha corpo nenhum, porra, senão cumé que o gajo ia mesmo pôr nome de capítulo missa de corpo ausente?, ele também num quer ser apanhado assim nos flagrantes literários..., e eu inda num tô grosso [bêbado]! (ONDJAKI, 2010, p. 151)

O caso narrado realmente não é nada crível: a experiência pós-morte relatada pelo próprio morto. Mas, segundo os conceitos aristotélicos, a literatura é um ato de representação do mundo por meio da linguagem, sendo que o trabalho do literato não se restringe ao relato de eventos ocorridos, cabendo-lhe, pois, contar "coisas quais podiam acontecer, possíveis no ponto de vista da verossimilhança ou da necessidade" (ARISTÓTELES, 1981, p. 28). Nesse aspecto, a obra literária pode ser vista como peça autônoma, capaz de se explicar por si mesma, tornando-se desnecessário analisá-la por analogia à realidade empírica.

Há evidências de que a história narrada por AdolfoDido nasceu de sua mente criativa, uma vez que o narrador-personagem deixa explícito, principalmente no capítulo "Nos brilhos da madrugada", sólido conhecimento literário e preferência por autores que valorizam o telúrico, ao citar Guimarães Rosa e Manoel de Barros, entre outros escritores que são reverenciados ao longo da narrativa. Em outro momento, menciona sua participação em debates sobre literatura, ocasião em que emite opinião contrária à expressão "literatura negra", defendendo que "a literatura não era mais pra ser terreno do aparteide, porra, meu, porque literatura negra?, e branca ainda?!" (ONDJAKI, 2010, p. 111).

Quantas madrugadas tem a noite revela o quotidiano de uma Angola já imersa em um contexto globalizado, mas ainda em processo de mudança. Como já se disse, findadas as guerras coloniais, o sonhado ambiente de paz e liberdade não se estabelecera. Após sangrentas batalhas contra a subjugação colonialista, o recém emancipado Estado sofre conflitos internos, que obstaculizam a organização e o desenvolvimento econômico. Todo esse clima de instabilidade política resulta nas más condições de vida à grande maioria da população angolana, que se vê em meio a disputas pelo poder fomentadas pelos interesses políticos e econômicos de países como Estados Unidos, África do Sul e Rússia, e têm tolhidas suas perspectivas futuras.

Mesmo dotando o texto de admirável beleza poética, a obra de Ondjaki inicia-se com a imagem contemporânea de Angola, ou, mais especificamente, Luanda, coberta de problemas, a começar pelos estragos provocados pelas históricas chuvas que costumam assolar a região nos meses quentes do ano. E denuncia:

[...] As costuras do céu tinham rebentado e o costureiro-anjo tava de férias - e nós aqui, a aguentar as aquáticas consequências: mais calamidade menos calamidade, quem quer mesmo saber? Internacionalmente somos mais destacados é na guerra e na fome, única chuva que lhes interessa vir aqui sofrer é chuva petroleodiamantífera, tás a captar, uí?, outras chuvas das lamas dos mosquitos gordos de matar ndengues na febre das madrugadas, [...] ou chuva molhada nas nenhumas tendas e telhas dos deslocados provinciais da nossa guerra gorda, essas são chuvas pra pobres, e essas ninguém veio aqui pôr pele dele pra ser salpicado na visão dos olhos: andar já era nadar, conduzir já era navegar, viver já era sofrer. (ONDJAKI, 2010, p. 21) 
Nesse trecho, fica evidente a falta de infraestrutura da capital angolana, que, isolada, sofre as consequências do mau tempo enquanto tem suas riquezas minerais, principalmente 0 petróleo e o diamante, explorados por empresas de capital estrangeiro, que, seguindo as regras de mercado, pouco se importariam com os problemas sociais do local. Pelo texto, entrevê-se que o mundo direciona os olhos a Angola somente quando são repercutidos os casos de guerra e fome, dois temas com poder de sensibilizar a comunidade internacional, que se mantém alheia a problemas considerados comezinhos, inclusive os acarretados pelas constantes chuvas.

Sem desconsiderar que a guerra e a fome continuam a ser realmente duas graves questões sociopolíticas angolanas, o narrador, em referência à notícia da matança de numerosos rebanhos, na Europa, em virtude da "doença da vaca louca", propõe, ironicamente, soltar as "vacas loucas" nos diversos campos minados de Angola, pois isso tenderia a solucionar simultaneamente os dois problemas: "[teria] todas minas descobertas e carne pronta pra ser seca, guardada no mundo ou nos nossos estômagos..." (ONDJAKI, 2010, p. 32).

Se em Vozes na sanzala constatou-se o início da mudança da condição social feminina, como o caso de Kanvula, que reinvidicava o direito de escolher o próprio marido, em Quantas madrugadas tem a noite, mulheres com os sugestivos nomes de Eva e Madalena fundam o Sindicato Nacional das Prostitutas e buscam o fortalecimento e o reconhecimento da classe. Além disso, outras questões sociais são abordadas na narrativa, entre elas a incidência de crianças em situação de risco, representada pela personagem PCG, o preconceito contra albinos e a condição precária dos sistemas públicos de educação e saúde.

Ondjaki mostra, ainda, uma Angola que se abre às produções culturais brasileiras, a começar pelas telenovelas, que, há décadas, fazem parte da vida luandense. Ao longo da narrativa, são reproduzidas frases criativas expressas por Odorico Paraguaçu, o folclórico personagem da telenovela O Bem Amado, do dramaturgo Dias Gomes, que recebe a simpatia do narrador:

[...] até aparecer na televisão esse kota mesmo que eu te falo de vez em quando, o Odorico, quer dizer, sempre essa mania, ali não era mais o Odorico, era outro, porra, num ficou já pra sempre Odorico?, acho que ficou, melhor personagem que já assisti, kota mesmo que sou fã dele - chorei na morte dele com as minhas lágrimas sem vergonhas nenhumas. (ONDJAKI, 2010, p. 174)

Além das recorrentes citações de Odorico, há menção ao mercado do Roque Santeiro, a então maior feira comercial de Luanda, batizado com o nome de um outro personagem das telenovelas globais. Entretanto, apesar de todo esse contato com a realidade brasileira, o narrador não deixa de transparecer que, diferentemente das brasileiras, as novelas da vida real luandense não são fáceis de aguentar: "Aqui, as coisas do dia-a-dia são muito fortes" (ONDJAKI, 2010, p. 175).

Todos os elementos sociais destacados de Quantas madrugadas tem a noite parecem convergir a uma crítica à equivocada política de Angola pós-independência. 0 relato principal da obra, que mostra a disputa entre as duas senhoras pela pensão oferecida pelo Estado às viúvas de ex-combatentes, ilustra um modo de fazer política 
preso ao passado, o que impediria a construção de uma nova história no território angolano. Nesse sentido, são desveladas contradições do regime implantado pelo MPLA, que, mesmo sob a bandeira do socialismo, não deixou de produzir desigualdades. Uma das falas do personagem Jaí expressa a rejeição do individualismo, ao propor o fim de "leninismos mascarados de interesses mais que pessoais" (ONDJAKI, 2010, p. 160) e ao revelar que "dentro das igualdades parece há sempre uns mais iguais que os outros" (p. 160-61). Disputas como essas são expostas por Agualusa (2004), em um artigo denominado "Guerra e paz em Angola", no qual o escritor angolano descreve situações de barbáries cometidas pelos movimentos nacionalistas que lutavam contra a opressão da Metrópole e visavam à conquista do poder e aponta uma cultura de exclusão existente em Angola, a qual somente poderia ser combatida com a instalação de um governo plenamente democrático.

Assim, o discurso que se pode inferir da narrativa de Ondjaki é o de que as ideologias, sejam elas marxistas ou capitalistas, atualmente, servem apenas para fomentar discussões ("makas") e manter a estabilidade de grupos políticos e econômicos. Como pensou o personagem BurkinaFaçam, na inauguração do "sindicato das putas", "não fazia mais sentido dizer abaixo o imperialismo!" (ONDJAKI, 2010, p. 100), considerando mais adequado bradar um "abaixo as chuvas!", ou seja, lutar por causas mais concretas.

\section{Considerações finais}

Vozes na sanzala é uma mostra literária do engajamento político de seu autor, Uanhenga Xitu. A construção de personagens moldáveis como Kahitu ilustra não apenas a possibilidade de transformação a que o ser humano encontra-se suscetível, mas também evidencia um ponto de vista crítico em relação à mudança, que, embora inevitável, nem sempre traz em si valores positivos. Infere-se dessa obra que a boa mudança é uma construção coletiva, que se reverte em bem para toda a sociedade. Não são aceitáveis as transformações que apenas desconfiguram tradições e implicam desunião entre as classes.

Quantas madrugadas tem a noite preserva ainda aquele colorido típico das narrativas tradicionais africanas, mas deixa perceptível que os tempos são outros. Encerrado o momento de batalhas pela autonomia do povo angolano, a ordem atual seria consolidar um espaço nacional socialmente justo, independentemente das ideologias que disputam o poder. Mostra uma Angola pós-independência em tentativa de caminhar para frente, apesar de todas as deficiências advindas de décadas de conflitos. A ideia a permear essa narrativa talvez seja a de que Angola (re)construa seu futuro e, em vez de fomentar conflitos, gerados por ideais divergentes, parta para a ação, a fim de que solucione suas questões mais urgentes. Um desses problemas a serem resolvidos são as constantes chuvas, que deixam seus estragos, mas também, na obra de Ondjaki, cumprem a função simbólica de sinalizar um mundo sempre em transformação. 


\section{Referências}

AGUALUSA, José Eduardo. Guerra e paz em Angola. KOSMOPOLIS. Festa Internacional de la Literatura. Disponível em: <http://www.cccb.org/rcs_gene/agualusa-portu.pdf>. Acesso em: 8 jan. 2011.

ARISTÓTELES. Poética. In: ARISTÓTELES, HORÁCIO LONGINO. A poética clássica. Trad. Jaime Bruna. São Paulo: Cultrix/Editora da USP, 1981.

BOAVIDA, Américo. Angola: cinco séculos de exploração portuguesa. Lisboa: União dos Escritores Angolanos/Edições 70, 1981.

BOOTH, Wayne C. The rhetoric of fiction. 2. ed. Chicago (USA): University of Chicago, 1983.

DILOLWA, Carlos Rocha. Prefácio à edição angolana. In: BOAVIDA, Américo. Angola: cinco séculos de exploração portuguesa. Lisboa: União dos Escritores Angolanos/Edições 70, 1981.

FERREIRA, Manuel. Literaturas africanas de expressão portuguesa II. Lisboa: Bertrand, 1977.

GENETTE, Gérard. Discurso da narrativa. Lisboa: Arcádia, 1979.

ONDJAKI. Quantas madrugadas tem a noite. São Paulo: Leya, 2010.

SANTILLI, Maria Aparecida. Estórias africanas: história e antologia. São Paulo: Ática, 1985.

SERRANO, C.; WALDMAN, M. Memória d'África: a temática africana em sala de aula. São Paulo: Cortez, 2007.

VENÂNCIO, José Carlos. Literatura versus sociedade: uma visão antropológica do destino angolano. Lisboa: Vega, 1992.

XITU, Uanhenga. Vozes na Sanzala (Kahitu). In:"Mestre" Tamoda e Kahitu. São Paulo: Ática, 1984. (1a. ed. em setembro de 1976, Edição do autor, Luanda).

\section{Title}

Vozes na Sanzala (Kahitu), by Uanhenga Xitu, and Quantas Madrugadas tem a Noite, by Ondjaki: Literary Expressions of a Changing Society.

\section{Abstract}

The objective is to analyze two distinct periods of literary production in Angola: the first period is the Uanhenga Xitu literature of resistance, based on the reading of the narrative Vozes na sanzala (Kahitu) (1984), through which considerations of Kahitu character formation and its implications to the representation of the Angolan environment when it was still in the colonial period will be presented. The second period turns to a writing that depicts the everyday in contemporary Luanda in Quantas 
madrugadas tem a noite (2004), by Ondjaki. This search will enable the survey of narrative elements, as well as observations about the context of production. The changing processes through which passed the Angolan society will be highlighted. These processes will be analyzed both in the context of colonialism and postcolonialism, which is represented in the chosen contemporary narrative.

\section{Keywords}

African literature. Angolan narrative. Colonialism. Uanhenga Xitu. Ondjaki.

Recebido em 23.09.2011. Aprovado em 02.12.2011. 